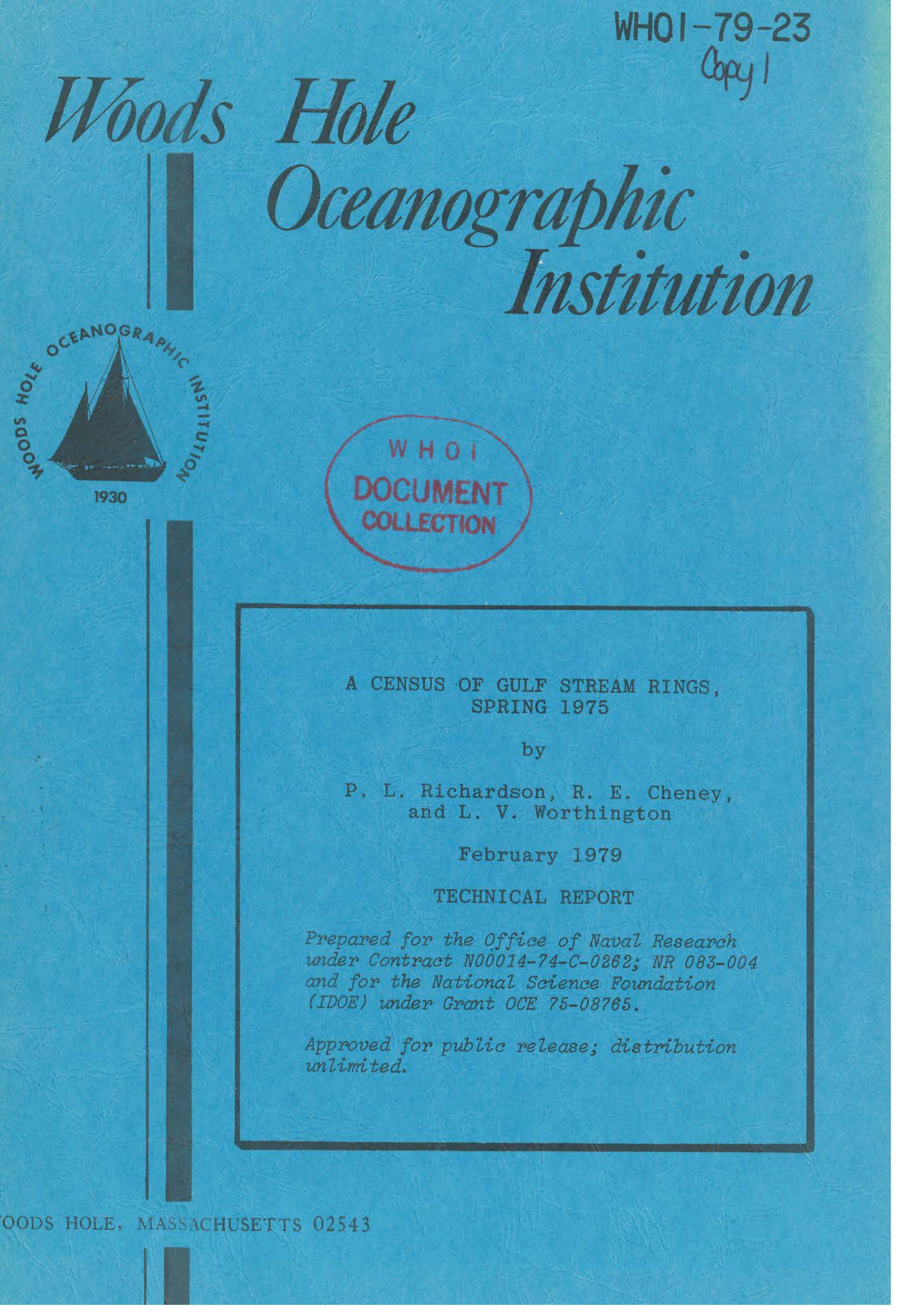


WHOI $-79-23$

\title{
A CENSUS OF GULF STREAM RINGS, SPRING 1975
}

\section{by}

P. L. Richardson, R. E. Cheney, and L. V. Worthington

\author{
WOODS HOLE OCEANOGRAPHIC INSTITUTION \\ Woods Hole, Massachusetts 02543
}

February 1979

\section{TECHNICAL REPORT}

Prepared for the Office of Naval Research under Contract N00014-74-C-0262; NR 083-004 and for the National Science Foundation under Grant OCE 75-08765.

Reproduction in whole or in part is permitted for any purpose of the United States Govermment. In citing this report in a bibliogrophy, the reference given should be to "Journal of Geophysical Research, Vol. 83, No. C12, December 20, 1978, pp. 6136-6144".

Approved for public release; distribution unZimited.

Approved for Distribution: Valentine Worthington, Chairman Department of Physical Oceanograph 


\title{
A Census of Gulf Stream Rings, Spring 1975
}

\author{
P. L. RICHARDSON \\ Woods Hole Oceanographic Institution, Woods Hole, Massachusetts 02543 \\ R. E. CHENEY ${ }^{1}$ \\ United States Naval Oceanographic Office, Washington, D. C. 20373 \\ L. V. WORTHINGTON \\ Woods Hole Oceanographic Institution, Woods Hole, Massachusetts 02543
}

\begin{abstract}
During 1975 several shipboard expendable bathythermograph surveys plus satellite infrared imagery provided a nearly synoptic view of the distribution and number of Gulf Stream rings in the western North Atlantic. Twelve rings were identified; nine were cyclonic (cold core) rings $\mathrm{nd}$ three were anticyclonic (warm core) rings. This is the largest number of rings ever observed during a short period of time (4 months). Evidence suggests that the mean movement of these rings was southwestward.
\end{abstract}

\section{INTRODUCTION}

Gulf Stream rings formed from large, 200- to 300-km diameter, meanders are an important part of the Gulf Stream system [Fuglister, 1972, 1977; Parker, 1971; Barrett, 1971; Saunders, 1971]. The formation of rings provides the dominant mechanism by which mass, momentum, vorticity, energy, and chemical and biological material are transported northward across the Gulf Stream into the slope water and southward into the Sargasso Sea. The intensity and the relatively long life (up to 2 years) of cold core rings [Fuglister, 1972, 1977; Cheney and Richardson, 1976; Lai and Richardson, 1977] suggest that they probably have a significant effect on the region where they are found.

During 1975 we were fortunate to have three ships measuring the thermal structure of a large part of the western North Atlantic during a 4-month period. When the results of these cruises are combined with data obtained from the National Oceanographic Data Center (NODC) and satellite infrared (IR) images, we are able, for the first time, to determine the distribution and number of rings in the western North Atlantic and to map the temperature structure of this region in considerable detail. Repeated observations of many of these rings have provided a measurement of their long-term, westward trajectories.

\section{DATA}

The primary data source was four large-scale expendable bathythermograph (XBT) surveys in the western North Atlantic during 1975. They were the following: Knorr 48, March 7 to April 16; Knorr 49, April 21 to May 19; Trident 168, May 24 to June 11; and Lynch 708-75, June 22 to July 9. Deep (760 m) XBT's and some conductivity, temperature, depth (CTD) and hydrographic stations were made along the track lines of each of these cruises. Although the purpose of the first two cruises was not a search for rings, several large rings were found in the eastern region [McCartney et al., 1978]. Results of these two cruises were particularly interesting as the rings were discovered in an area previously thought to be devoid of them [Parker, 1971]. The purpose of the two subsequent cruises was to find as many rings as possible in the western region and to measure their size and shape.

Data from these cruises plus all additional XBT's and hy-

${ }^{1}$ Now at NASA Goddard Space Flight Center, Greenbelt, Maryland 20771.

Copyright (c) 1978 by the American Geophysical Union.

Paper number $8 \mathrm{C} 0789$.

0148-0227/78/128C-0789\$01.00 drographic data on file at NODC for the period MarchAugust 1975 were plotted on maps covering successive 2-week periods. The location of the Gulf Stream and rings near it that were visible on NOAA satellite infrared imagery were added to the maps and used to fill in areas lacking ship observations. There was a significant amount of overlap between surveys, and some major features (meanders, rings) were observed on several of them. A final composite map (Figure 1) was prepared from the biweekly maps; it covers a 4-month period from March 10 to July 9, 1975.

Topography of the $15^{\circ} \mathrm{C}$ isotherm was chosen in order to describe the Gulf Stream and rings. This isotherm extends from the sea surface in the north to a depth of about $800 \mathrm{~m}$ just south of the Gulf Stream, and this range is well covered by 760-m XBT's. In the North Atlantic the average depth of the $15^{\circ} \mathrm{C}$ surface lies about $250 \mathrm{~m}$ shallower than the $10^{\circ} \mathrm{C}$ surface which was contoured by Iselin [1936] and Fuglister [1963]. The $15^{\circ} \mathrm{C}$ surface lies within the main thermocline, and because of the linear TS relation and nearly constant vertical temperature gradient in the main thermocline, contours representing topography of the $15^{\circ}$ surface have a pattern similar to that of dynamic height contours. However, the reader must be cautioned that a depression of the $15^{\circ}$ surface is dynamically 'high' and an elevation of the $15^{\circ}$ surface is dynamically 'low.'

Another chart portraying the 'mean' $15^{\circ}$ isothermal topography was prepared (Figure 2) to show the mean shape of the Gulf Stream and subtropical gyre. The chart was based on the mean temperature maps of Lai [1977] and Lai and Richardson [1977] in which ring observations were excluded. The effect of including rings in such a map is shown by Dantzler [1977] and shifts the center of the gyre (or the location where the $15^{\circ}$ isotherm reaches its greatest depth) to the south.

Observations of each ring are given in Table 1. Topography of the $15^{\circ}$ surface in each ring and vertical temperature sections through each of the major features are shown in Figures 3 and 4 .

An attempt was made to determine the trajectories of each ring, and the results are shown in Figure 5. The method described by Lai and Richardson [1977] was used. The movement of warm core rings was determined chiefly from analyses of satellite IR images [NAVOCEANO, 1975; NOAA/NESS, $1975 ;$ NOAA/NWS, 1975]. The movement of cold core rings was obtained from many different methods including XBT and AXBT surveys, Sofar floats, satellite drifters, and satellite IR images. A list of positions of the cold core rings is given in Table 2. 


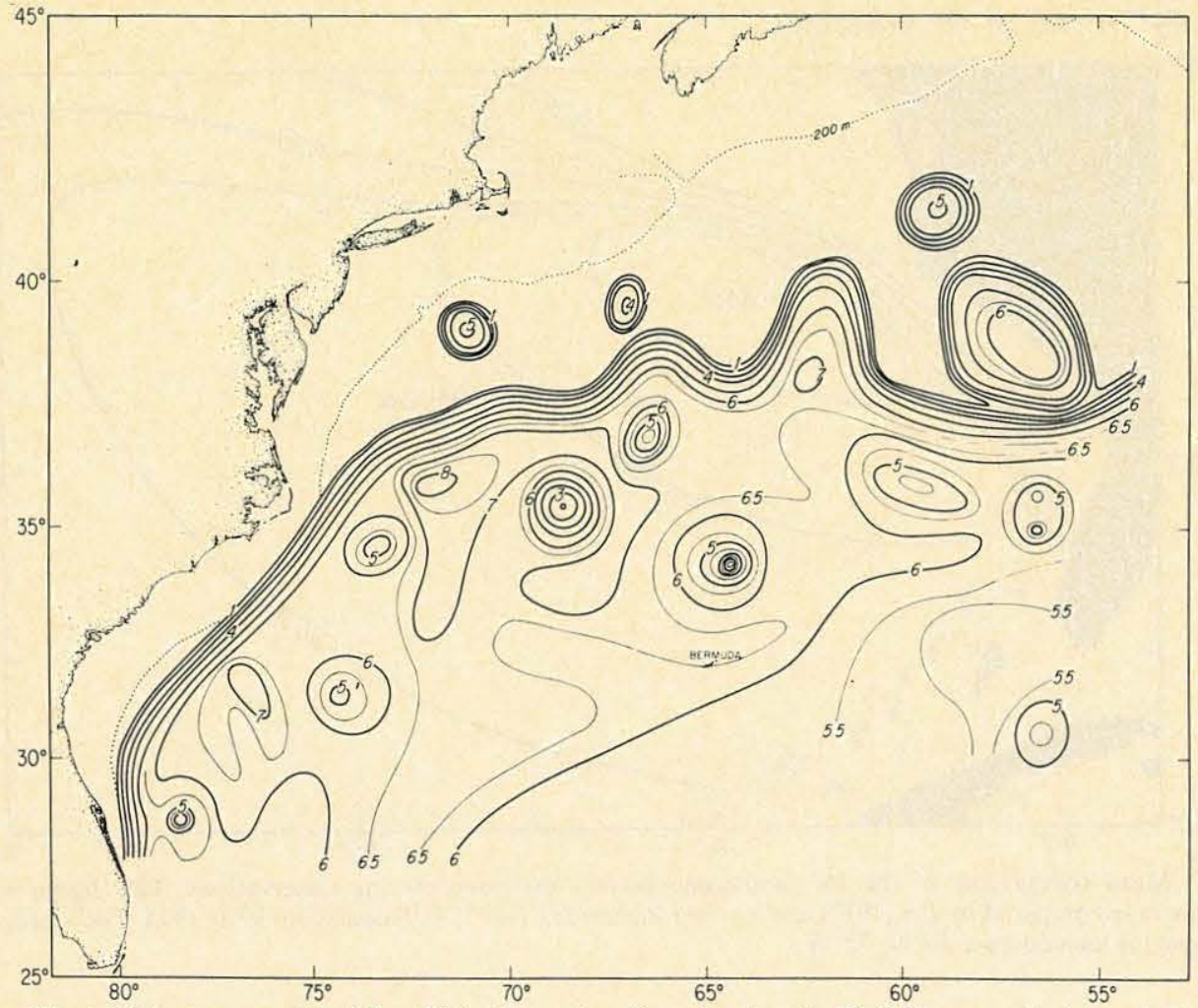

Fig. 1a. Chart of the topography of the $15^{\circ}$ isothermal surface showing the Gulf Stream and nine cyclonic and three anticyclonic rings. Contours are based on XBT, CTD, and hydrographic data over the period March 16 to July 9, 1975. Contours in two anticyclonic rings north of the Gulf Stream and in portions of the Gulf Stream are based on satellite infrared imagery.

\section{RESULTS}

The Gulf Stream is characterized by an abrupt north-south deepening of the $15^{\circ}$ isotherm from $100 \mathrm{~m}$ in the slope water region to $700 \mathrm{~m}$ in the Sargasso Sea (Figure $1 a$ ). Thus the Gulf
Stream can be seen as a meandering zone about $100 \mathrm{~km}$ wide extending from the Florida Straits to $55^{\circ} \mathrm{W}$. Southeastward of the Gulf Stream the thermocline gradually rises again as part of the Gulf Stream recirculation [Worthington, 1977]. The

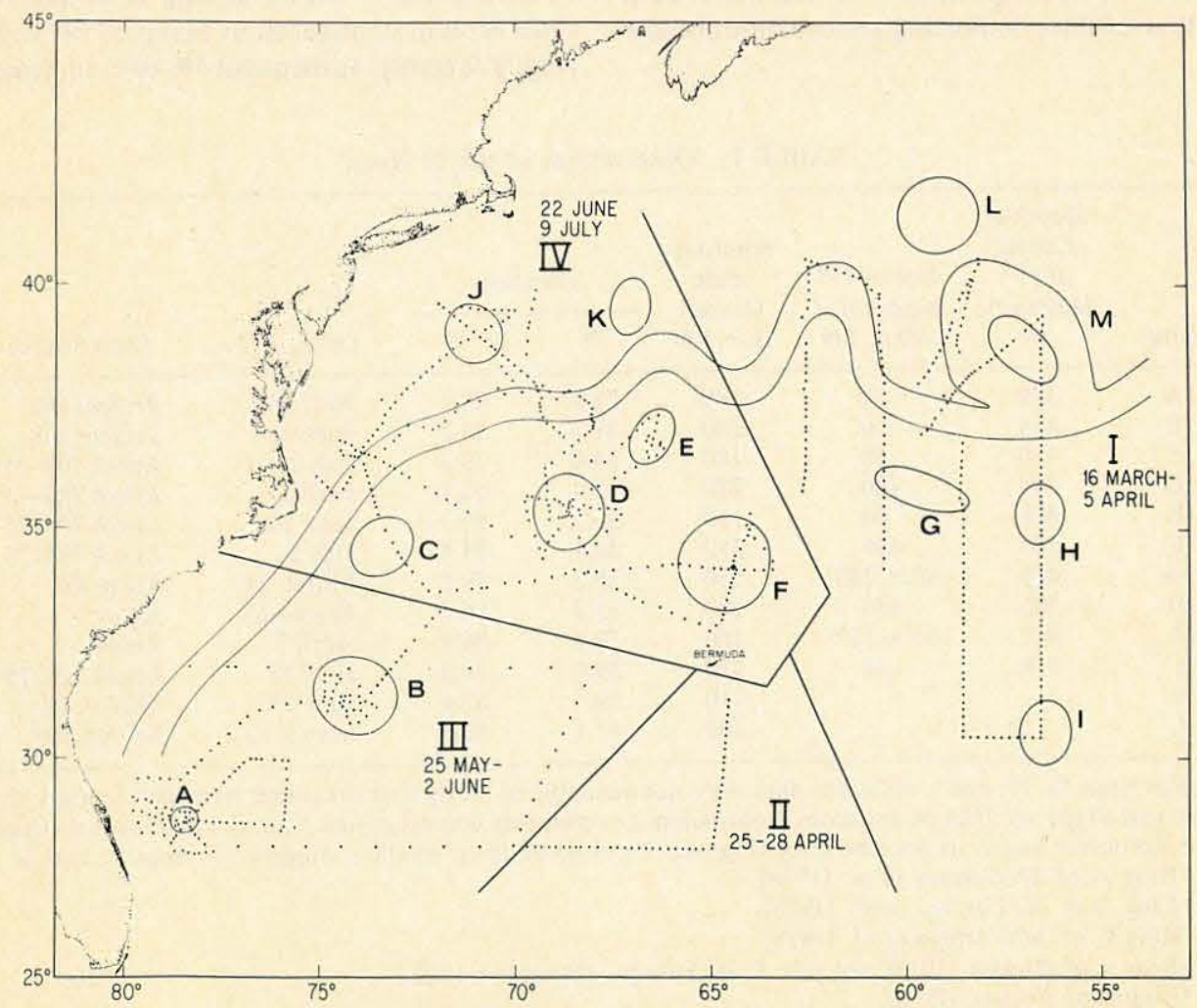

Fig. $1 b$. Location and dates of the observations. 
DEPTH (M) of $15^{\circ}$ SURFACE

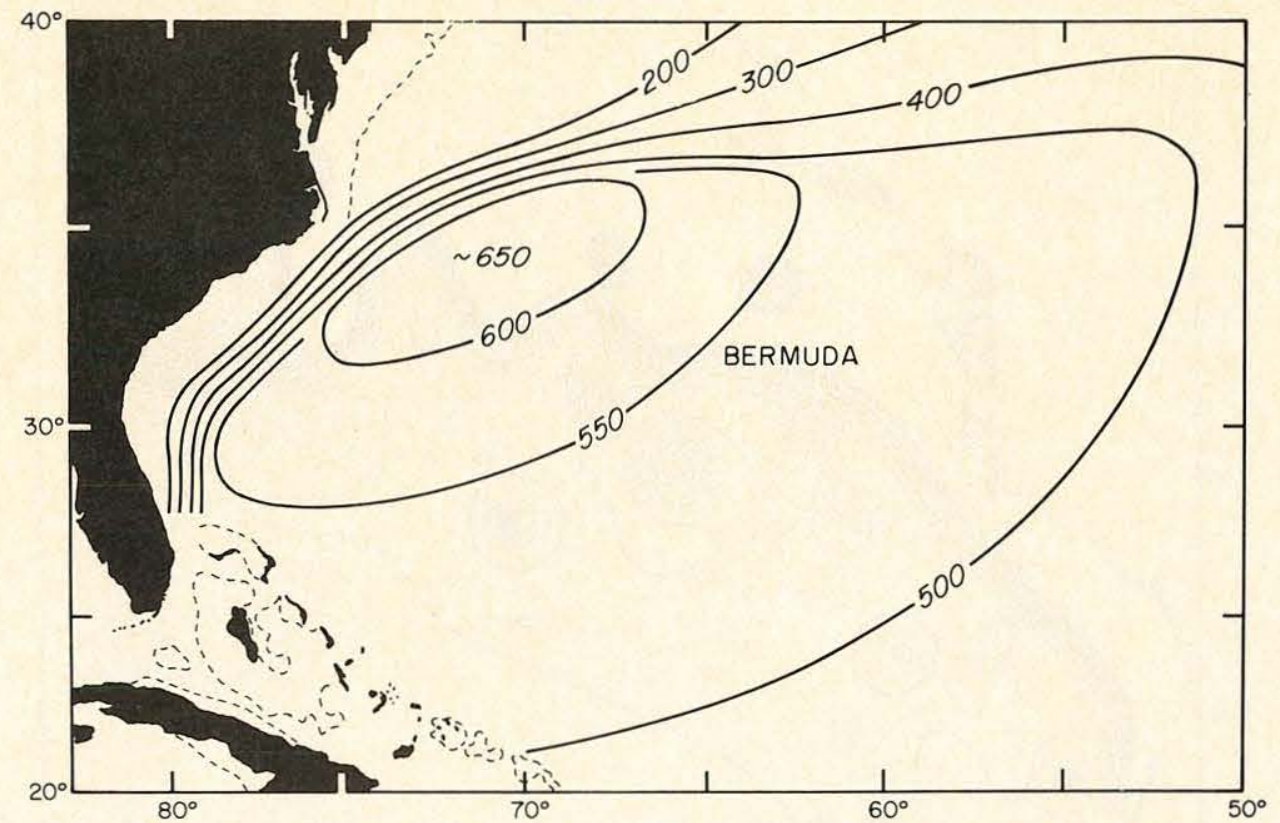

Fig. 2. Mean topography of the $15^{\circ}$ isothermal surface exclusive of ring observations. This figure is based on temperature maps prepared by Lai [1977] and Lai and Richardson [1977] with data from 1970-1974. The center of the gyre (deepest spot) is located near $36^{\circ} \mathrm{N}, 72^{\circ} \mathrm{W}$.

areas north and south of the Gulf Stream are populated by intense rings manifested as elevations and depressions. Three anticyclonic warm core rings (manifested by depression of the $15^{\circ}$ isotherm) are found north of the Gulf Stream, and nine cyclonic cold core rings (manifested by elevation at the $15^{\circ}$ isotherm) are found south of it. Because of limited data in some regions (Figure $1 b$ ) it is possible that there are a few additional rings that were not observed. Immediately south of the Gulf Stream and between rings, there are a number of deep depressions in the thermocline, indicating anticyclonic circulation.

\section{Gulf Stream}

The Gulf Stream forms a meander along $62^{\circ} \mathrm{W}$ and a meander/ring along $57^{\circ} \mathrm{W}$. A careful examination of satellite IR and XBT data suggests the following sequence of events. The $62^{\circ} \mathrm{W}$ meander formed when an earlier warm core ring coalesced with the Gulf Stream in early March. This meander formed another warm core ring by mid-April which moved westward and is shown as ring $\mathrm{K}$ in late June. Although the Gulf Stream configuration along $57^{\circ} \mathrm{W}$ suggests that a warm ring is forming, subsequent IR data indicate that this ring did

TABLE 1. Observations of the 12 Rings

\begin{tabular}{|c|c|c|c|c|c|c|c|}
\hline \multirow[b]{2}{*}{ Ring } & \multirow{2}{*}{$\begin{array}{c}\text { Depth at } \\
\text { Center } \\
\text { of } 15^{\circ} \\
\text { Isotherm, } \\
\mathrm{m}\end{array}$} & \multirow{2}{*}{$\begin{array}{l}\text { Size of } 15^{\circ} \\
\text { Isotherm at } \\
500 \mathrm{~m}, \mathrm{~km}\end{array}$} & \multirow{2}{*}{$\begin{array}{c}\text { Approxi- } \\
\text { mate } \\
\text { Overall } \\
\text { Size, km }\end{array}$} & \multicolumn{2}{|c|}{ Location } & \multirow[b]{2}{*}{ Date, 1975} & \multirow[b]{2}{*}{ Data Source } \\
\hline & & & & ${ }^{\circ} \mathrm{N}$ & ${ }^{\circ} \mathrm{W}$ & & \\
\hline A & 330 & 70 & 180 & 28.6 & 78.4 & May 26 & Trident 168 \\
\hline B & 458 & 50 & 200 & 31.3 & 74.2 & June 1 & Trident 168 \\
\hline C & 480 & 50 & 180 & 34.6 & 73.3 & July 2 & Lynch 708-75 \\
\hline D & 204 & 120 & 220 & 35.4 & 68.6 & June 25 & Lynch $708-75^{a}$ \\
\hline $\mathrm{E}$ & 408 & 60 & 150 & 36.7 & 66.5 & June 28 & Lynch 708-75 \\
\hline $\mathrm{F}$ & 203 & 105 & 250 & 34.1 & 64.4 & July 5 & Lynch 708-75 \\
\hline G & 465 & $80 \times 220 ?$ & 250 & 35.8 & 59.5 & March 24 & Knorr $48^{b}$ \\
\hline $\mathrm{H}$ & 385 & 130 & 200 & 35.3 & 56.5 & March 25 & Knorr ${ }^{c}$ \\
\hline I & 407 & $85 \times 135 ?$ & 160 & 30.5 & 56.5 & April 3 & Knorr \\
\hline J & 518 & 45 & 120 & 39.0 & 71.0 & June 29 & Lynch $708-75^{d}$ \\
\hline $\mathrm{K}$ & & & 110 & 39.5 & 67.4 & June 29 & NOAA IR ${ }^{e}$ \\
\hline $\mathrm{L}$ & & & 160 & 41.1 & 59.0 & March 19 & NOAA IR ${ }^{\prime}$ \\
\hline
\end{tabular}

For rings $\mathrm{G}, \mathrm{H}$, and $\mathrm{I}$, sufficient data were not available to verify that the center had been crossed; the size and shape are thus in question. Approximate overall size was estimated from the diameter at which the isotherms began to become level (Figures 3 and 4 ) or from satellite imagery for rings $\mathrm{K}$ and $\mathrm{L}$.

${ }^{a}$ Ring A of McCartney et al. [1978].

${ }^{b}$ Ring B of McCartney et al. [1978].

${ }^{c}$ Ring C of McCartney et al. [1978].

${ }^{d}$ Ring 6 of Bisagni [1976]; see also Gulf Stream, December 1975.

${ }^{e}$ Ring 8 of Bisagni [1976].

${ }^{\prime}$ Ring 10 of Bisagni [1976]. 

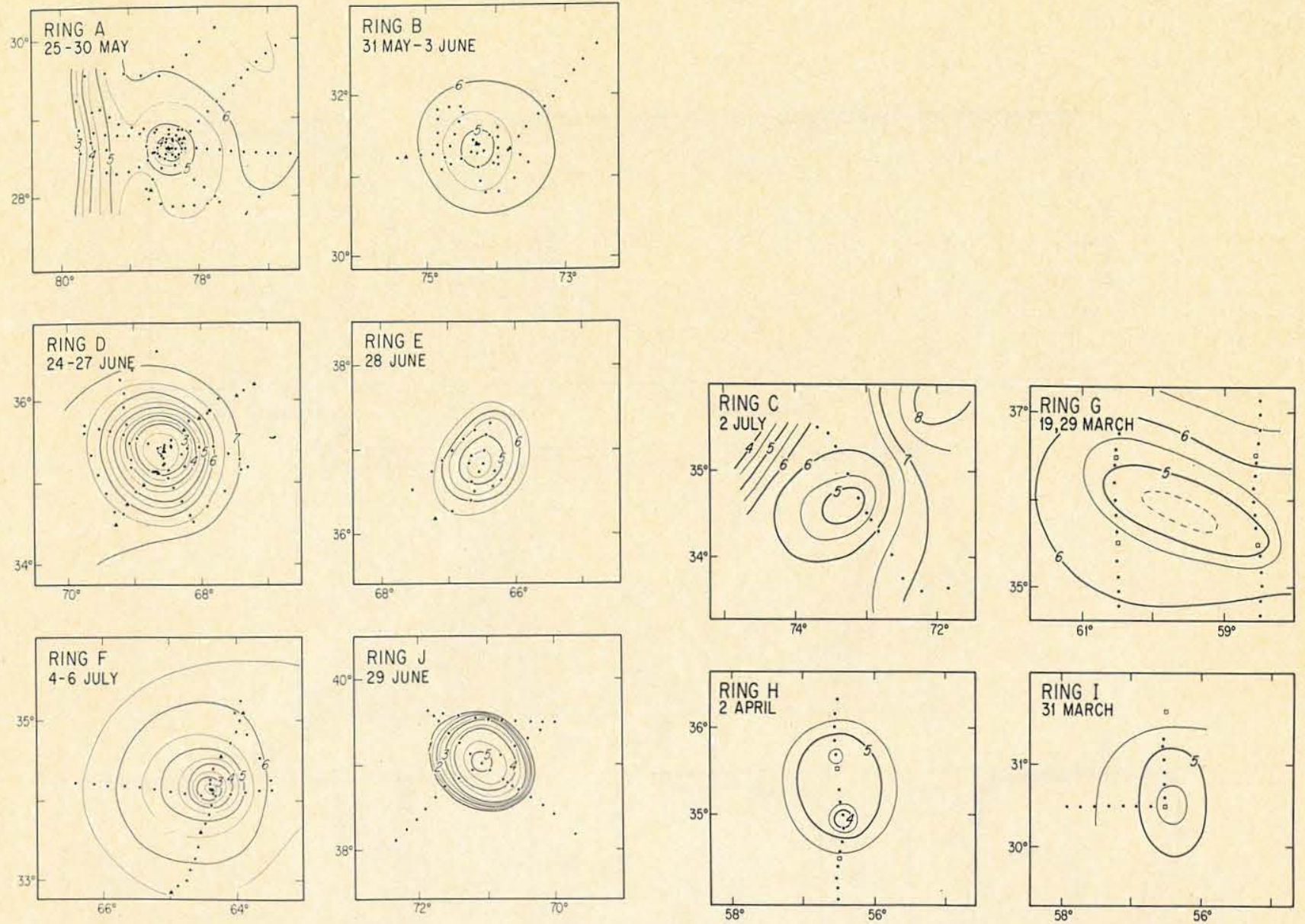

Fig. 3. Detailed maps of each ring showing the topography of the $15^{\circ}$ surface in hectometers. Dots represent XBT's, triangles represent CTD or STD stations, and squares represent hydrographic casts. Rings A, B, D, E, F, and J are well surveyed rings, and rings $\mathrm{C}, \mathrm{G} . \mathrm{H}$, and I are poorly surveyed rings.

not completely separate and that there continued to be a large meander in this region at least until July 1975. It is possible that a ring did detach in this region but that it remained undetected.

Frequently, with closely spaced XBT sections, one can see what resembles a depressed trough, a maximum in the depths of isotherms, on the offshore side of the Gulf Stream (Figure $4 a)$. This trough marks the location where currents reverse direction from the eastward flow of the Gulf Stream to the westward flow of the recirculation. Occasionally, there are deep depressions in the thermocline significantly deeper than the usual trough. An example of one is located near $36^{\circ} \mathrm{N}$ and $72^{\circ} \mathrm{W}$ where the $15^{\circ} \mathrm{C}$ depth reaches $810 \mathrm{~m}$ (Figure $4 a$, section 3 ). Occasionally, cold core rings, especially young ones, also appear to have a small depressed trough in the thermocline near their outer edges (Figure $4 a$, rings $\mathrm{D}$ and $\mathrm{H}$ ). A possible explanation is that when cold core rings form from a meander, this trough detaches with the ring. The deep depressions may reflect the coincidence of troughs associated with the Gulf Stream and rings. Apparently, it is above those deep depressions that much of the renewal of the $18^{\circ} \mathrm{C}$ water [Worthington, 1959] takes place. On Knorr cruise 65 in April 1977 we found a deep depression with $15^{\circ} \mathrm{C}$ at $845 \mathrm{~m}$ located near $34.4^{\circ} \mathrm{N}, 71.3^{\circ} \mathrm{W}$. Above this spot was a vertically homogeneous water mass with a temperature of $18.4^{\circ} \mathrm{C}$ extending from the surface to $500 \mathrm{~m}$. It had apparently just formed during the winter of 1976-1977 [Leetmaa, 1977; Worthington, 1977]. This deep spot was centered between three cyclonic rings. Later, in December 1977, an especially deep spot was measured from the Endeavor by XBT (W. G. Metcalf, personal communication, 1977). Eighteen-degree water was observed to extend to $825 \mathrm{~m}$ near $34.0^{\circ} \mathrm{N}, 68.5^{\circ} \mathrm{W}$. Although the $15^{\circ}$ isotherm was not reached, its depth was estimated to be 1000 $\mathrm{m}$ from the vertical temperature gradient between $15^{\circ}$ and $18^{\circ}$ near this location and time.

\section{Rings}

Nine cold core rings, three warm core rings, and one ring/ meander were found in this study. Of the cold core rings, A, B, $\mathrm{D}, \mathrm{E}$, and $\mathrm{F}$ were adequately sampled to determine reasonable estimates of their size and shape (Table 2, Figure 3). The others, C, G. H, and I, were not sampled well, and the contouring is largely conjectural. Although $\mathrm{C}, \mathrm{G}, \mathrm{H}$, and I all clearly appear to be rings, we suspect that the XBT sections did not pass through their centers and thus their intensity could be underestimated. Of the warm core rings, only $\mathrm{J}$ was well surveyed by XBT. The others $\mathrm{K}$ and L, were repeatedly observed with satellite IR images, although there were no XBT's to document the temperature structure. Contours (Figure 1) were drawn consistent with the IR data and sections through other warm core rings. Occasionally, the water in a warm core ring can be cooled below $15^{\circ} \mathrm{C}$ during the winter, and if this should occur, the ring would not appear on a contoured $15^{\circ}$ surface. The evidence suggests that ring $\mathrm{M}$ never completely separated from the Gulf Stream and remained part of a meander at least until July 1975. 


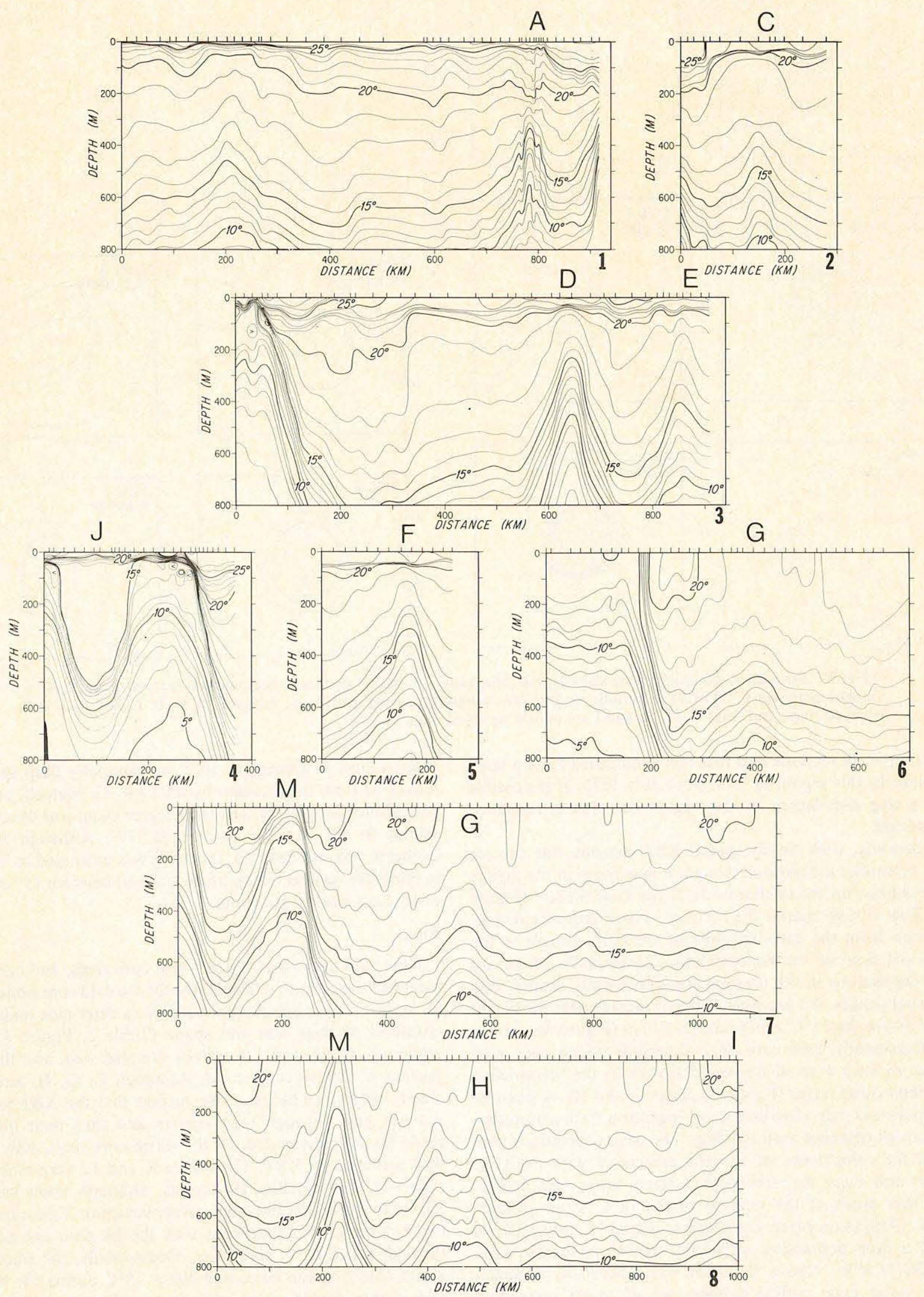

Fig. 4a. Vertical temperature sections through the Gulf Stream and rings based on XBT data. Letters A-I refer to individual rings. 


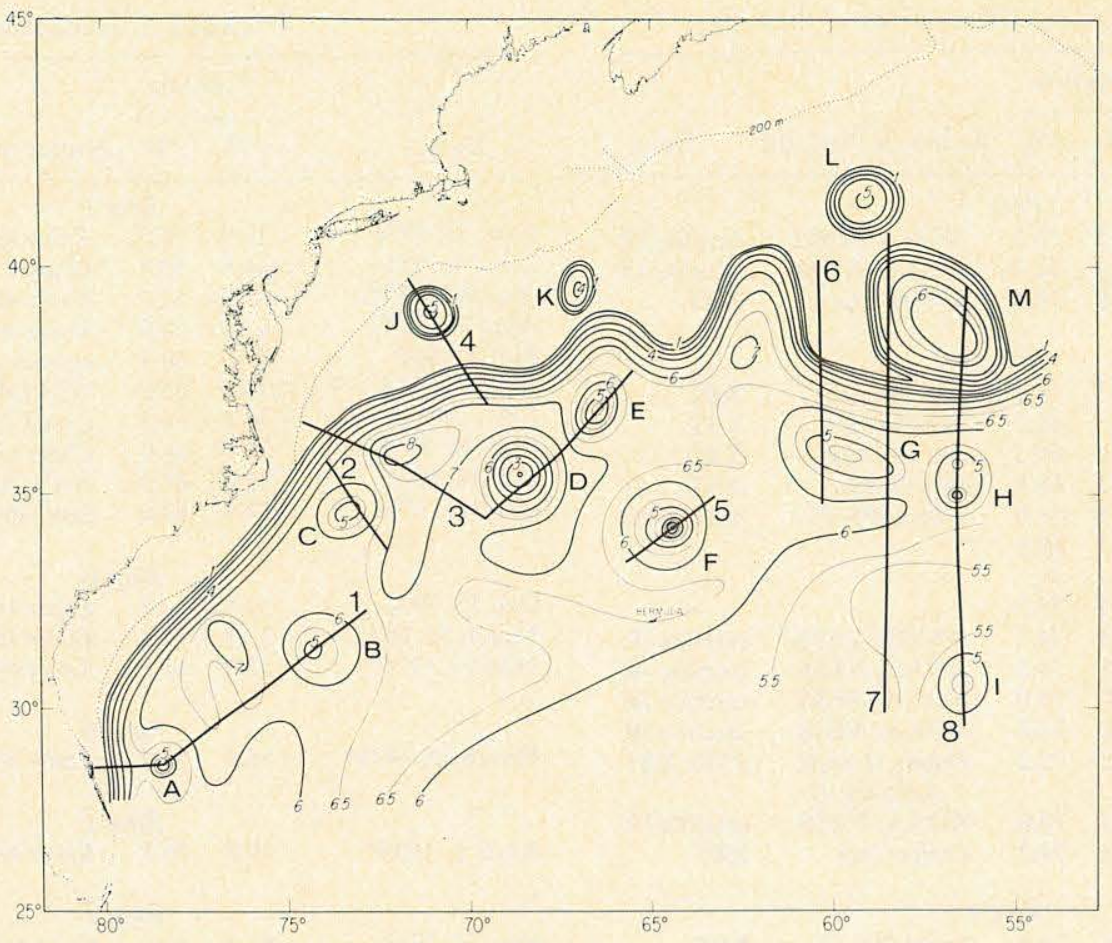

Fig. $4 b$. Location of $\mathrm{XBT}$ sections.

The character of the cold core rings east of about $60^{\circ} \mathrm{W}$ appears to be different from that of the rings to the west (Figures 3 and 4 ). The western rings appear nearly round; they have steep sides and a single peak. Eastern rings appear lumpier, have less slope to their flanks, and may not be very round (see the work of McCartney et al. [1978] for additional sections through the eastern rings). A possible explanation is that as the Gulf Stream passes over the New England Seamoun Chain, it is split into filaments and made broader [Fuglister, 1963; Vastano and Warren, 1976]. Rings which form east of the seamount chain may reflect the Gulf Stream's character at the time of formation and therefore look different from the rings formed west of the seamount chain. McCartney et al. [1978] concluded that the eastern rings could have formed at the eastern extremity of the gyre, near $40^{\circ} \mathrm{W}$, and moved westward.

Movement of the rings, inferred from repeated sightings and sometimes continuous tracking, is shown in Figure 5 (Table 2). For some of the rings the data are very good (B, D, J, K, and L), but for others it is spaced widely in time (A, E, F, and G) or nonexistent $(\mathrm{C}, \mathrm{H}$, and $\mathrm{I})$, and therefore the trajectories of some rings are not very reliable. The general movement of the rings is to the southwest with typical mean speeds of $3-4 \mathrm{~km} / \mathrm{d}$ This is in agreement with the results of Lai and Richardson [1977] based on a larger sample of rings. Apparently, few rings penetrate below $30^{\circ} \mathrm{W}$ except in the extreme western region, where they are found extending south to the Bahama Islands. Ring A was found attached to the Gulf Stream and presumably coalescing with it. The following is a brief description of each ring.

Ring $A$. Ring A was well surveyed by XBT in May 1975. It appears to be attached to the Gulf Stream and may be coalescing with it as another ring is believed to have done [Richardson et al., 1973]. Two possible earlier sightings (Table 2) indicate a possible southwestward movement.

Ring B. Ring B was tracked from June 1974 to June 1975 by successive XBT surveys and satellite IR images and from October to January, 1974, by Sofar floats [Cheney et al., 1976].

Ring $C$. Ring $\mathrm{C}$ was observed with only one XBT section across it, and thus its size and shape remain in question.

Ring D. Ring D is one of the best studied rings to date. It was first observed in March 1975 and was tracked until February 1977 with repeated ship and aircraft surveys, satellite IR images, and a free drifting buoy. There is good evidence for a mean southwestward movement at $3 \mathrm{~cm} \mathrm{~s}^{-1}$, at least until ring D reaches the vicinity of the Blake Bahama Outer Ridge and Blake Escarpment, where the movement became erratic and difficult to follow.

Ring E. Ring E is a small ring, possibly one first observed on Knorr 48 in April 1975. There are several possible sightings which suggest that ring $E$ also had a mean southwestward movement.

Ring $F$. Ring $\mathrm{F}$ is a large ring which moved westward after its initial obsérvation in November 1974. McCartney et al. [1978] have described in detail the movement, velocity, and density structure of this ring.

Ring $G$. Ring $\mathrm{G}$ was observed with only two north-south XBT lines in March which were made 10 days apart. The data were interpreted as indicating a single ring whose center lies between the XBT lines. The size and shape of ring $\mathrm{G}$ remain in doubt. Evidence for the movement of this ring is slight and consists of three possible sightings over 7 months.

Ring $H$. Ring $\mathrm{H}$ was observed with only one north-south $\mathrm{XBT}$ line, and it was contoured with the assumption that it was symmetrical. Ring $\mathrm{H}$ was observed to have two peaks like other rings in the eastern region [McCartney et al., 1978].

Ring I. Ring I was observed by an XBT crossing in its northwest quadrant. Its size and shape are largely extrapolated. The amplitude of ring I is not great, $100-150 \mathrm{~m}$, but the XBT lines could have missed its center, and therefore this ring could be considerably more intense than is shown.

Ring J. Ring J was first seen on December 31, 1974, near 
TABLE 2. Repeated Observations of the Rings

\begin{tabular}{ll}
\hline & Position \\
\cline { 2 - 3 } Date & ${ }^{\circ} \mathrm{N}$ Source or Platform Data
\end{tabular}

Feb. 15,1975
March 23, 1975

May 26, 1975*

June 17,1974

July 15,1974

July 29,1974

Aug. 12, 1974

Sept. 29, 1974

Sept. 29, 1974

to

Dec. $15,1974 \dagger$

Jan. 22, 1974

Jan. 27, 1975

Feb. 12, 1975

March 23, 1975

April 9, 1975

April 26, 1975

June 1, 1975*

July 2, 1975

March 24, 1975

April 10, 1975

April 24, 1975

May 12, 1975

May 21,1975

June 7,1975

June 17, 1975

June $25,1975^{*}$

July 8, 1975

Aug. 8, 1975

Sept. 3, 1975

Sept. 10, 1975

Sept. 26, 1975

Oct. 14, 1975

Oct. 14, 1975

Nov. 20, 1975

Jan. 6, 1976

Jan. 13, 1976

Feb. 5, 1976

Feb. 11, 1976

Feb. 14, 1976

Feb. 25, 1976

Feb. 29, 1976

March 1, 1976

March 7, 1976

April 24, 1976

May 20, 1976

June 7, 1976

June 7, 1976

$$
\text { to }
$$

Sept. 10, $1976 \ddagger$

Sept. 20, 1976

Oct. 5, 1976

Dec. 17, 1976

Feb. 23, 1977

April 11, 1975 April 24, 1975

June 28, 1975*

July 4, 1975

Aug. 4, 1975

Sept. 2, 1975

Sept. 30, 1975

Oct. 16,1975

\section{Ring $A$}

$\begin{array}{lll}30.5 & 76.5 \quad \text { NOAA/NESS }\end{array}$

$28.678 .4 \quad$ Trident $168 \quad$ XBT

\section{Ring $B$}

\begin{tabular}{ccll}
34.2 & 65.0 & Sea Venture & XBT \\
33.5 & 66.0 & Sea Venture & XBT \\
34.0 & 66.3 & Sea Venture & XBT \\
34.2 & 66.8 & Sea Venture & XBT \\
32.5 & 69.0 & Lynch 708-75 & XBT, STD \\
32.5 & 69.0 & & \\
to & to & & \\
33.5 & 73.0 & & \\
33.5 & 74.7 & NAVOCEANO & satellite IR \\
32.5 & 74.3 & NOAA/NESS & satellite IR \\
32.0 & 75.0 & NOAA/NESS & satellite IR \\
31.0 & 75.6 & NOAA/NESS & satellite IR \\
31.2 & 75.2 & Duane, Lynch, & STD, XBT \\
& \multicolumn{3}{c}{ Advance II } \\
30.5 & 76.0 & NOAA/NESS & satellite IR \\
31.3 & 74.2 & Trident 168 & XBT
\end{tabular}

$\begin{array}{llll}31.3 & 74.2 & \text { Trident } 168 & \text { XBT }\end{array}$

Ring C

$\begin{array}{llll}34.5 & 73.3 & \text { Lynch } 708-75 & \text { X BT }\end{array}$

$$
\text { Ring } D
$$

$\begin{array}{lll}36.5 & 66.2 \quad \text { NOAA/NESS }\end{array}$

$\begin{array}{ll}36.5 & 66.7\end{array}$

$36.0 \quad 66.8$

$\begin{array}{ll}35.7 & 67.2\end{array}$

$\begin{array}{ll}35.7 & 67.7\end{array}$

$35.9 \quad 68.3$

$35.5 \quad 68.5$

$35.4 \quad 68.6$

$35.7 \quad 69.5$

$\begin{array}{ll}34.6 & 69.9\end{array}$

$\begin{array}{ll}35.2 & 70.0\end{array}$

$\begin{array}{ll}35.3 & 70.7\end{array}$

$\begin{array}{ll}34.5 & 70.7\end{array}$

$34.8 \quad 70.8$

$35.0 \quad 71.0$

$33.9 \quad 71.9$

$33.8 \quad 73.0$

$33.6 \quad 73.2$

$33.5 \quad 73.6$

$\begin{array}{ll}33.5 & 73.7\end{array}$

$33.8 \quad 73.8$

$33.7 \quad 73.4$

$33.7 \quad 73.3$

$33.6 \quad 73.6$

$33.0 \quad 73.5$

$32.5 \quad 74.0$

$32.2 \quad 75.0$

$31.8 \quad 75.5$

$31.8 \quad 75.5$

to to

$\begin{array}{ll}31.9 & 75.1\end{array}$

$32.3 \quad 75.1$

$\begin{array}{ll}32.3 & 74.2\end{array}$

$31.0 \quad 75.3$

$30.0 \quad 75.3$

NA VOCEANO

AAVOCEANO satellite IR

Ring $E$

$35.964 .5 \quad$ Knorr $48 \quad$ XBT

$36.0 \quad 64.5 \quad$ NOAA/NESS satellite IR

$37.0 \quad 66.5 \quad$ Lynch 708-75 XBT

36.5 66.4 NAVOCEANO satellite IR

$36.0 \quad 67.0 \quad$ NOAA/NESS satellite IR

$35.2 \quad 67.0 \quad$ Gulf Stream

$35.0 \quad 67.7$ Gulf Stream

34.2 66.6 NAVOCEANO AXBT's

\begin{tabular}{|c|c|c|c|c|}
\hline \multirow[b]{2}{*}{ Date } & \multicolumn{2}{|c|}{ Position } & \multirow[b]{2}{*}{ Source or Platform } & \multirow[b]{2}{*}{ Data } \\
\hline & ${ }^{\circ} \mathrm{N}$ & ${ }^{\circ} \mathrm{W}$ & & \\
\hline \multicolumn{5}{|c|}{ Ring $F$} \\
\hline Nov. 15,1974 & 34.8 & 56.5 & Knorr 43 & XBT \\
\hline Jan. 24,1975 & 34.6 & 59.8 & Chain 118 & XBT \\
\hline March 25, 1975 & 34.2 & 62.7 & Knorr 48 & XBT \\
\hline April 30,1975 & 33.6 & 64.0 & Knorr 49 & XBT \\
\hline May 1,1975 & 33.0 & 64.3 & current meter & velocity \\
\hline June 17,1975 & 34.0 & 65.0 & NAVOCEANO & AXBT \\
\hline July $5,1975^{*}$ & 34.1 & 64.3 & Lynch 708-75 & $\mathrm{XBT}$ \\
\hline Sept. 15, 1975 & 33.8 & 68.0 & Chain 127 & XBT \\
\hline Oct. 16,1975 & 33.0 & 67.5 & NAVOCEANO & AXBT \\
\hline Oct. 16,1975 & 33.3 & 67.0 & Eastward & XBT \\
\hline \multicolumn{5}{|c|}{ Ring $G$} \\
\hline Oct. 15,1974 & 37.8 & 56.5 & Knorr 48 & XBT \\
\hline March 24,1975 & 35.8 & 59.5 & Knorr 48 & XBT \\
\hline May $17,1975^{*}$ & 35.2 & 61.5 & Knorr 49 & XBT \\
\hline \multicolumn{5}{|c|}{ Ring $H$} \\
\hline March $25,1975^{*}$ & 35.5 & 56.4 & Knorr 48 & XBT \\
\hline \multicolumn{5}{|c|}{ Ring I } \\
\hline April $3,1975^{*}$ & 30.5 & 56.5 & Knorr 48 & XBT \\
\hline \multicolumn{5}{|c|}{ Ring $J$} \\
\hline Dec. 31, 1974 & 41.3 & 62.0 & $\begin{array}{l}\text { NOAA/NWS } \\
\text { (vol. } 1 \text {, no. 12) }\end{array}$ & $\begin{array}{l}\text { satellite IR } \\
\text { (first formed) }\end{array}$ \\
\hline June $29,1975^{*}$ & 39.0 & 71.0 & Lynch & XBT \\
\hline Nov. 5,1975 & 36.0 & 74.0 & NAVOCEANO & $\begin{array}{l}\text { satellite IR } \\
\text { (coalesced) }\end{array}$ \\
\hline \multicolumn{5}{|c|}{ Ring $K$} \\
\hline April 15,1975 & 40.2 & 63.5 & NAVOCEANO & $\begin{array}{l}\text { satellite IR } \\
\text { (first } \\
\text { observed) }\end{array}$ \\
\hline June $22,1975^{*}$ & 39.5 & 67.1 & NAVOCEANO & satellite IR \\
\hline July $6,1975^{*}$ & 39.5 & 67.7 & NAVOCEANO & satellite IR \\
\hline Dec. 20,1975 & 35.5 & 74.5 & NA VOCEANO & $\begin{array}{l}\text { satellite IR } \\
\text { (coalesced) }\end{array}$ \\
\hline \multicolumn{5}{|c|}{ Ring $L$} \\
\hline March $19,1975^{*}$ & 41.1 & 59.0 & NOAA/NESS & $\begin{array}{l}\text { satellite IR } \\
\text { (first formed) }\end{array}$ \\
\hline March 24, 1976 & 36.5 & 73.0 & NAVOCEANO & $\begin{array}{l}\text { satellite IR } \\
\text { (coalesced) }\end{array}$ \\
\hline
\end{tabular}

TABLE 2. (continued)

Warm rings can be followed throughout their lifetimes with satellite IR imagery; trajectories in Figure 5 were determined primarily from NAVOCEANO [1975]. Additional position information has been found in Gulf Stream (December, 1975) and in Bisagni's [1976] report. *Observations used in Figure 1.

†Tracked by Sofar floats [Cheney et al., 1976].

$\ddagger$ Tracked by free drifting satellite buoy.

$41.3^{\circ} \mathrm{N}, 62.0^{\circ} \mathrm{W}$ and last seen on November 5,1975 , coalescing with the Gulf Stream off Cape Hatteras near $36.0^{\circ} \mathrm{N}, 74.0^{\circ} \mathrm{W}$. An isothermal, $15.5^{\circ} \mathrm{C}$ layer formed by winter cooling extended from 70 to $430 \mathrm{~m}$ at its center when it was observed in June 1975.

Ring $K$. Ring $\mathrm{K}$ formed from the meander shown in Figure 1 along $62^{\circ} \mathrm{W}$ in mid-April 1975 near $40.2^{\circ} \mathrm{N}, 63.5^{\circ} \mathrm{W}$. It moved southwestward and coalesced with the Gulf Stream by the end of December 1975 near $35.5^{\circ} \mathrm{N}, 74.5^{\circ} \mathrm{W}$. Ring K was observed solely with satellite IR images.

Ring $L$. Ring L formed in mid-March 1975 near $41.1^{\circ} \mathrm{N}$, $59.0^{\circ} \mathrm{W}$. It moved southwestward, possibly coalescing with the Gulf Stream and reforming again in May 1975. By March 24, 1976 , it had coalesced with the Gulf Stream near $36.5^{\circ} \mathrm{N}$, $73.0^{\circ} \mathrm{W}$. Ring $\mathrm{L}$ was observed solely with satelite IR images. 


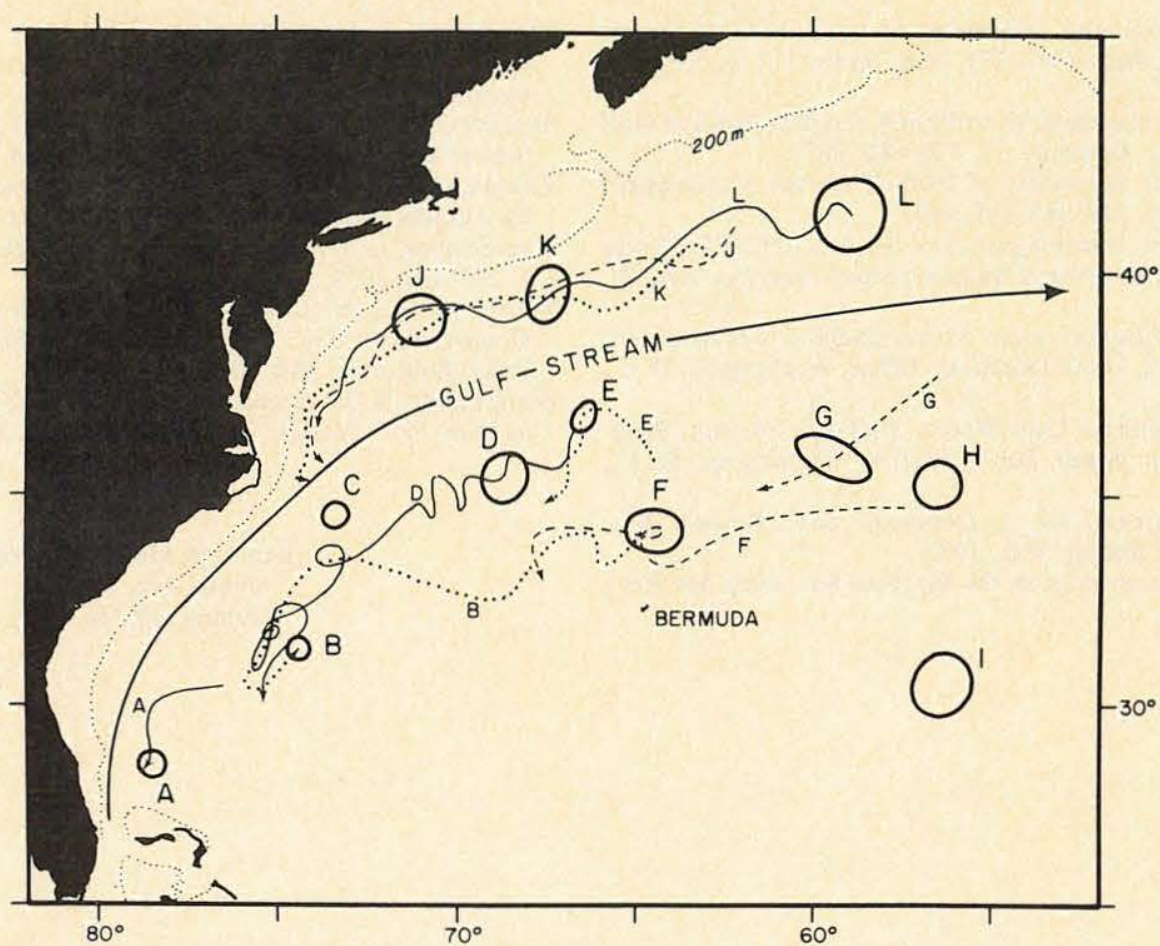

Fig. 5. Inferred trajectories of the rings. Trajectories are based on successive observations and reasonable velocities (see text).

\section{Discussion}

For the first time a 'weather map' has been prepared for a 4month period of the western North Atlantic Ocean. The map shows the location of the Gulf Stream and the distribution of warm and cold core rings. Two important questions about this map need to be answered. The first is how much distortion occurs in the map due to movement of the features during the 4-month period over which the data were obtained. The second is whether it represents typical or anomalous conditions.

The map can be divided into four regions in which the data can be considered synoptic, e.g., the movement of the major features (rings) was relatively small compared to the size of the features. A potential problem occurs where the edges of these regions meet. The worst difficulty is between regions I and IV where there is a gap in time of 11 weeks. The Gulf Stream did not appear to make large shifts across this boundary except for the formation of ring $\mathrm{K}$. There was apparently a westward movement of the rings, but no ring moved so far as to be shown twice. The effect of the time jump between regions I and IV is to spread out the rings in an east-west direction. If the western region had been surveyed first, the rings would have appeared more crowded. One can imagine that if region I had been surveyed 4 months later, the whole pattern could have moved west, and an additional ring could have moved into the region.

We have compared Figure 1 with other, more limited XBT surveys and satellite IR data for other periods of time and conclude that it represents a rather typical picture of the Gulf Stream system. The region to the north of the Gulf Stream frequently has three rings in it as seen on satellite infrared images. However, at times, no rings can be seen there, and at other times, as many as six rings can be identified. The few occasions for which simultaneous satellite IR and XBT measurements exist, for example, during June 1975, have confirmed our identification of rings with infrared images.
Rings to the south of the Gulf Stream are not easily detectable on satellite IR images, and we need to depend on deep XBT's, CTD's, or hydrographic stations. Recent data in the 1970's tend to confirm that the distribution of cold core rings shown in Figure 1 is typical, or at least is not anomalous [Lai and Richardson, 1977; McCartney et al., 1978].

Acknowledgments. We are pleased to acknowledge the support of the International Decade of Ocean Exploration of the National Science Foundation under grant OCE75-08765 and the Office of Naval Research under contract N00014-74-C-02621 NR 083-004. George Heimerdinger helped obtain data from NODC. NOAA/NESS provided the satellite infrared imagery. Claes Rooth provided data taken from the R/V Gillis which were not available at NODC. This paper is contribution number 4126 of the Woods Hole Oceanographic Institution and number 102 of the Mid-Ocean Dynamics Experiment.

\section{REFERENCES}

Barrett, J. R., Available potential energy of Gulf Stream rings. Deep Sea Res., 18, 1221-1231, 1971.

Bisagni, J. J., Passage of anticyclonic Gulf Stream eddies through deepwater dumpsite 106 during 1974 and 1975, NOAA Dumpsite Evaluation, Rep. 76-1, 39 pp., Dep. of Commer., Washington, D. C., 1976.

Cheney, R. E., and P. L. Richardson, Observed decay of a cyclonic Gulf Stream ring, Deep Sea Res., 23, 143-155, 1976.

Cheney, R. E., W. H. Gemmill, M. K. Shank, P. L. Richardson, and D. Webb, Tracking a Gulf Stream ring with Sofar floats, J. Phys. Oceanogr., 6, 741-749, 1976.

Dantzler, H. L., Potential energy maxima in the tropical and subtropical North Atlantic, J. Phys. Oceanogr., 7, 512-519, 1977.

Fuglister, F. C., Gulf Stream '60, Progr. Oceanogr., 1, 265-283, 1963.

Fuglister, F. C., Cyclonic Gulf Stream rings formed by the Gulf Stream 1965-66, in Studies in Physical Oceanography, vol. 1, pp. 137-167, Gordon and Breach, New York, 1972.

Fuglister, F. C., A cyclonic ring formed by the Gulf Stream 1967, in $A$ Voyage of Discovery, pp. 177-198, Pergamon, New York, 1977.

Iselin, C. O'D., A study of the circulation of the western North Atlantic, Pap. Phys. Oceanogr. Meteorol., 4(4), 101 pp., 1936. 
Lai, D. Y., Distribution and movement of cyclonic Gulf Stream rings from historical data (1970-73), M.S. thesis, $117 \mathrm{pp}$; Univ. of R. I., Kingston, 1977.

Lai, D. Y., and P. L. Richardson, Distribution and movement of Gulf Stream rings, J. Phys. Oceanogr., 7, 670-683, 1977.

Leetmaa, A., Effects of the winter of 1976-77 on the northwestern Sargasso Sea, Science, 198, 188-189, 1977.

McCartney, M. S., L. V. Worthington, and W. J. Schmitz, Jr., Large cyclonic rings from the northeast Sargasso Sea, J. Geophys. Res., 83, 901-914, 1978.

NAVOCEANO, Experimental ocean frontal analysis, weekly charts, Fleet Appl. Dep., U.S. Naval Oceanogr. Office, Washington, D. C., 1975.

NOAA/NESS, Experimental Gulf Stream analysis, Environ. Prod. Group, Nat. Environ. Satell. Serv., NOAA, Washington, D. C., 1975.

NOAA/NWS, Gulf Stream, vol. 1, Oceanogr. Serv. Branch, Nat. Weather Serv., Silver Spring, Md., 1975.

Parker, C. E., Gulf Stream rings in the Sargasso Sea, Deep Sea Res., 18, 981-994, 1971.
Richardson, P. L., A. E. Strong, and L. A. Knauss, Gulf Stream eddies: Recent observations in the western Sargasso Sea, J. Phys. Oceanogr., 3, 297-301, 1973.

Saunders, P. M., Anticyclonic eddies formed from shoreward meanders of the Gulf Stream, Deep Sea Res., 18, 201-219, 1971.

Vastano, A. C., and B. A. Warren, Perturbations to the Gulf Stream by Atlantis II seamount, Deep Sea Res., 23, 681-694, 1976.

Worthington, L. V., The $18^{\circ}$ water in the Sargasso Sea, Deep Sea Res. 5, 297-305, 1959 .

Worthington, L. V., On the North Atlantic Circulation, Johns Hopkins Oceanographic Ser., vol. 6, 110 pp., Johns Hopkins University Press, Baltimore, Md., 1976.

Worthington, L. V., Intensification of the Gulf Stream after the winter of 1976-1977, Nature, 207(5636), 415-417, 1977.

(Received March 29, 1978;

revised July 26, 1978;

accepted July 26, 1978.) 


\begin{tabular}{|c|c|}
\hline REPORT DOCUMENTATION PAGE & $\begin{array}{c}\text { READ INSTRUCTIONS } \\
\text { BEFORE COMPLETING FORM }\end{array}$ \\
\hline \begin{tabular}{l|l} 
1. REPORT NUMBER & 2. GOVT ACCESSION NC \\
WHOI $-79-23$ &
\end{tabular} & 3. RECIPIENT'S CATALOG NUMBER \\
\hline $\begin{array}{l}\text { 4. TITLE (and Subtite) } \\
\text { A CENSUS OF GULF STREAM RINGS, SPRING } \\
1975\end{array}$ & $\begin{array}{l}\text { 5. TYPE OF REPORT \& PERIOD COVERED } \\
\text { Technical }\end{array}$ \\
\hline & $\begin{array}{l}\text { 6. PERFORMING ORG. REPORT NUMBER } \\
\text { WHOI CON. NO. } 4126\end{array}$ \\
\hline $\begin{array}{l}\text { 7. AUTHOR(s) } \\
\text { P. L. Richardson, R. E. Cheney and } \\
\text { L. V. Worthington }\end{array}$ & $\begin{array}{l}\text { 8. CONTRACT OR GRANT NUMBER(s) } \\
\text { NO0014-74-C-0262; } \\
\text { OCE 75-08765 }\end{array}$ \\
\hline $\begin{array}{l}\text { 9. PERFORMING ORGANIZATION NAME AND ADDRESS } \\
\text { Woods Hole Oceanographic Institution } \\
\text { Woods Hole, MA } 02543\end{array}$ & $\begin{array}{l}\text { 10. PROGRAM ELEMENT, PROJECT, TASK } \\
\text { AREA A WORK UNIT NUMBERS } \\
\text { NR } 083-004\end{array}$ \\
\hline $\begin{array}{l}\text { 11. CONTROLLING OFFICE NAME AND ADDRESS } \\
\text { NORDA } \\
\text { National Space Technology Laboratory } \\
\text { Bay St. Louis, MS } 39529\end{array}$ & $\begin{array}{l}\text { 12. REPORT DATE } \\
\text { February } 1979 \\
\text { 13. NUMBER OF PAGES }\end{array}$ \\
\hline 14. MONITORING AGENCY NAME \& ADDRESS(II different from Controlling Oflico) & $\begin{array}{l}\text { 15. SECURITY CLASS. (of this roport) } \\
\text { UnClasSi fied } \\
\text { 15a. DECLASSIFICATION/DOWNGRADING } \\
\text { SCHEDULE }\end{array}$ \\
\hline
\end{tabular}

17. DISTRIBUTION STATEMENT (of the abotract entered in Block 20, if difforent from Roport)

18. SUPPLEMENTARY NOTES

Reprinted from "Journal of Geophysical Research, Vol. 83, No. C12, December 20, 1978, pp. 6136-6144".

19. KEY WORDS (Continue on feverse aido if neceseary and ldentily by block number)

1. Gulf Stream Rings

2. Census of Rings in 1975

3. Movement of Rings in 1975

20. ABSTRACT (Continue on reverse side if necessary and identify by block number)

During 1975 several shipboard expendable bathythermograph surveys plus satellite infrared imagery provided a nearly synoptic view of the distribution and number of Gulf Stream rings in the western North Atlantic. Twelve rings were identified; nine were cyclonic (cold core) rings and three were anticyclonic (warm core) rings. This is the largest number of rings ever observed during a short period of time (4 months). Evidence suggests (Cont. on 



\section{MANDATORY DISTRIBUTION LIST}

FOR UNCLASSIFIED TECHNICAL REPORTS, REPRINTS, AND FINAL REPORTS

PUBLISHED BY OCEANOGRAPHIC CONTRACTORS

OF THE OCEAN SCIENCE AND TECHNOLOGY DIVISION

OF THE OFFICE OF NAVAL RESEARCH

(REVISED NOVEMBER 1978)

1 Deputy Under Secretary of Defense (Research and Advanced Technology) Military Assistant for Environmental Science Room 3D129

Washington, D.C. 20301

Office of Naval Research

800 North Quincy Street

Arlington, VA 22217

3 ATTN: Code 483

1 ATTN: Code 460

2 ATTN: 102B

1 CDR J. C. Harlett, (USN) ONR Representative Woods Hole Oceanographic Inst. Woods Hole, MA 02543

Commanding Officer Naval Research Laboratory Washington, D.C. 20375

6 ATTN: Library, Code 2627
12 Defense Documentation Center Cameron Station

Alexandria, VA 22314

ATTN: DCA

Commander

Naval Oceanographic Office NSTL Station

Bay St. Louis, MS 39522

ATTN: Code 8100

ATTN: Code 6000

ATTN: Code 3300

$1 \quad$ NODC/NOAA

Code D781

Wiscons in Avenue, N.W. Washington, D.C. 20235 


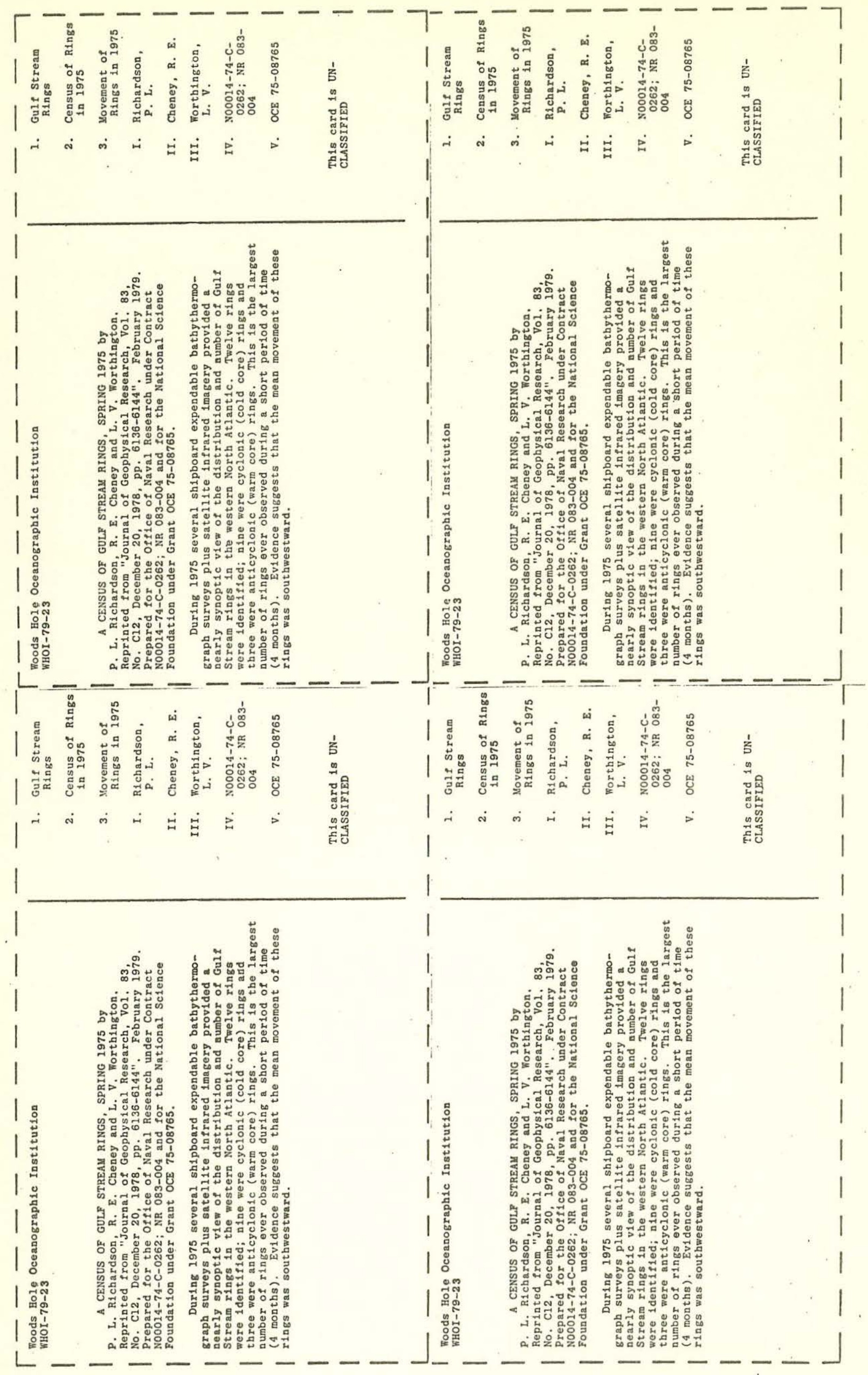

